\title{
ANALISIS KELAYAKAN POLA USAHATANI AGROTRISULA KOMERING SEJAHTERA V DI DESA BANTAN KECAMATAN BUAY PEMUKA PELIUNG OKU TIMUR
}

\author{
(Aisah)
}

\begin{abstract}
The purpose of this research were to: (1) To know the characteristic and technical details, the supporting factor and the constraint of farming pattern of agrotrisula done to farmer group KBS V Desa Bantan, (2) To analyze the profit and feasibility of agrotrisula farming system done to the group Farmer KBS V Desa Bantan. This research was conducted in Bantan Village Buay Pemuka Peliung District, OKU Timur, South Sumatra Province. Location deliberation is done deliberately with the consideration that the Village is one of the pilot Village of agrotrisula farming system in East OKU Regency, when viewed agroclimate the area is very suitable for agrotrisula developed in terms of topography, soil condition and climate. Data collection was carried out until January 2015. This research found that the combination of business that is done is horticulture crops such as long bean, cucumber, sweet corn, ground kangkung, and spinach pull, fishery is cultivation of catfish sangkuriang and farm that is cultivation of bali cattle. Business management is done intensively with commercial purpose, there is special characteristic which is fried by farming group that is application of technology of probiotic bacteria to spur the increase of hormone which can directly increase the growth of both plants, livestock and fish. The total area of cultivated land which KBS V cultivated is $0.32 \mathrm{Ha}$.Total production costs are sacrificed in one period of agricultural production pattern of agrotrisula pattern of Rp. 22.618.167. The analysis of $R / C$ Ratio is 1.38, which means that every one rupiah sacrificed as business capital will get revenue equal to 1.38 rupiah, and it means feasible to be digested, and ROI (Return On Investment) analysis is obtained value 177\% And categorized as very efficient.
\end{abstract}

Key Words : Agrotrisula, Agribusiness Development Management, Integrated Agriculture.

\section{PENDAhuluaN}

\section{A. Latar Belakang}

Agrotrisula merupakan suatu konsep pengelolaan sumberdaya alam dan lingkungan secara terpadu pada usaha bidang pertanian sebagai upaya untuk mengoptimalisasikan, efisiensi dan peningkatkan produktifitas lahan pertanian. Agrotrisula berasal dari dua suku kata agro dan trisula. Agro berarti hal yang terkait dengan proses atau hasil pertanian (Anonim, 2011). Trisula/trishula/serampang (sanskerta : trishul) berarti tombak bermata tiga yang secara harpiah berarti tiga tombak (Anonim, 2013). Agrotrisula berarti suatu pola usahatani yang mengkombinasikan tiga cabang usaha bidang pertanian terdiri dari pertanaman holtikultura, peternakan dan perikanan yang diusahakan dalam satu siklus waktu dan luasan wilayah yang sama serta saling memiliki keterkaitan yang tidak dapat dilepaskan antara komoditas satu dengan yang lainya, berorientasi ekologis sehingga diperoleh peningkatan nilai ekonomi, tingkat efisiensi dan produktifitas tinggi.

Pertanian terintegrasi bukan hanya melakukan berbagai usaha pertanian (dua atau lebih usahatani) tetapi menekankan adanya simpul-simpul yang menyatukan atau menghubungkan diantara aktivitas usahatani yang satu dengan sistem usahatani yang lainya. Pengembangan pertanian secara terintegrasi dengan mengoptimalkan segala potensi yang dipunyai sangat tepat dikembangkan oleh masyarakat karena akan meningkatkan hasil produksi dan penekanan biaya produksi yang dikeluarkan oleh petani. (Anonim, 2012).

Pola usahatani agrotrisula yang dikelola secara ekologis akan meningkatkan kandungan bahan organik di dalam tanah dan penyebaran karbon lebih rendah jika dibandingkan dengan pertanian konvensional yang menggunakan pupuk nitrogen dan pupuk kimia sintetis lainya. Agar proses pemanfaatan tersebut dapat terjadi secara efektif dan efisien maka sebaiknya produksi pertanian berada dalam satu kawasan. Pada kawasan tersebut sebaiknya terdapat komoditas produksi tanaman, peternakan dan perikanan. Keberadaan komoditas ini akan mengakibatkan kawasan tersebut memiliki ekosistem yang lengkap dan seluruh komponen produksi tidak akan menjadi limbah. Karena limbah yang dihasilkan oleh satu komoditi akan dimanfaatkan oleh komoditi lainya dan juga sebaliknya. Sehingga terjalin hubungan timbal balik yang menguntungkan, hal tersebutlah yang dapat menekan biaya produksi namun tetap meningkatkan produktifitas (Anonim, 2012). 
Pengembangan pola usahatani agrotrisula di Kabupaten OKU Timur Provinsi Sumatra Selatan merupakan merupakan hal yang baru bagi masyarakat tani. Karena pada umumnya masyarakat menerapkan pola pertanian konvensional. Pola agrotrisula di Kabupaten OKU Timur pertama kali dikenalkan oleh Prof. Dr. Ir. Fachrurrozie Sjarkowi, M.Sc, dengan melakukan pemberdayaan terhadap masyarakat suku komering yang merupakan penduduk asli OKU Timur. Program tersebut direalisasikan sejak bulan sebtember 2014, terdapat lima desa yang menjadi desa binaan anatara lain: Desa Betung, Rasuan, Pandan Agung, Riang Bandung, Dan Banten. Pada masing-masing desa tersebut dibentuk satu kelompok inti yang diberi nama Komering Bangkit Sejahtera ( KBS ) satu sampai lima yang diurutkan dari hilir ke hulu.

Desa Bantan merupakan salah satu Desa binaan tentang pola usahatani agrotrisula tersebut. Komoditas yang diusahakan antara lain: komoditas sayuran dan holtikultura, ternak sapi, dan ikan lele, yang dikelola secara terintegrasi dengan menggunakan teknologi bakteri. Teknologi bakteri mampu mengikat nitrogen bebas yang diubah menjadi ammonia, kemudian disalurkan keseluruh bagian tanaman. Selain itu teknologi bakteri juga mampu meningkatkan hormon tanaman yang secara langsung mempengaruhi pertumbuhan tanaman. Dengan pengembangan pola agrotrisula diharapkan potensi lahan pertanian masyarakat dapat dimanfaatkan secara optimal, efisien, dan memiliki produktifitas tinggi yang dapat memberikan sumbangan pendapatan lebih kepada masyarakat.

Dalam pengembangan usaha-usaha pertanian (agribisnis) lebih dahulu harus diadakan analisis ekonomi dan analisis finansial terhadap proyek tersebut. Untuk mengetahui prospek pengembangan usahatani sebagai usaha yang menguntungkan perlu adanya penilaian terhadap usaha yang akan dicapai. Penilaian ini dapat dijadikan dasar persetujuan atau penolakan pengembangan selain itu petani perlu mempertimbangkan sejauh mana modal yang ditanamkan akan menghasilkan keuntungan dan seberapa besar keuntungan yang diperoleh. Oleh karena itu perlu dipelajari kapan usaha tersebut balik modal, kapan usaha tersebut menguntungkan dan bagaimana cara meningkatkan keuntungan usaha tersebut. Bagi petani keuntungan yang didapatkan adalah peningkatan pendapatan yang diterimanya. Untuk mencapai tujuan tersebut diperlukan analisis secara ekonomi tentang kelayakan finansial usahatani agrotrisula, sehingga usaha tersebut layak untuk dikembangkan.

\section{B. Rumusan Masalah}

1. Bagaimana tehnis usahatani pola agrotrisula yang dilakukan pada KBS V Desa Bantan.

2. Berapa kinerja usahatani pola agrotrisula pada KBS V Desa Bantan jika dilihat secara finansial.

\section{Tujuan dan Kegunaan}

1. Untuk mengetahui ciri dan rincian teknis, faktor pendukung maupun kendala usahatani pola agrotrisula yang dilakukakan pada kelompok tani KBS V Desa Bantan.

2. Untuk menganalisis laba usaha dan tingkat kelayakan usahatani agrotrisula yang dilakukan pada kelompok tani KBS V Desa Bantan.

\section{Model Pendekatan}

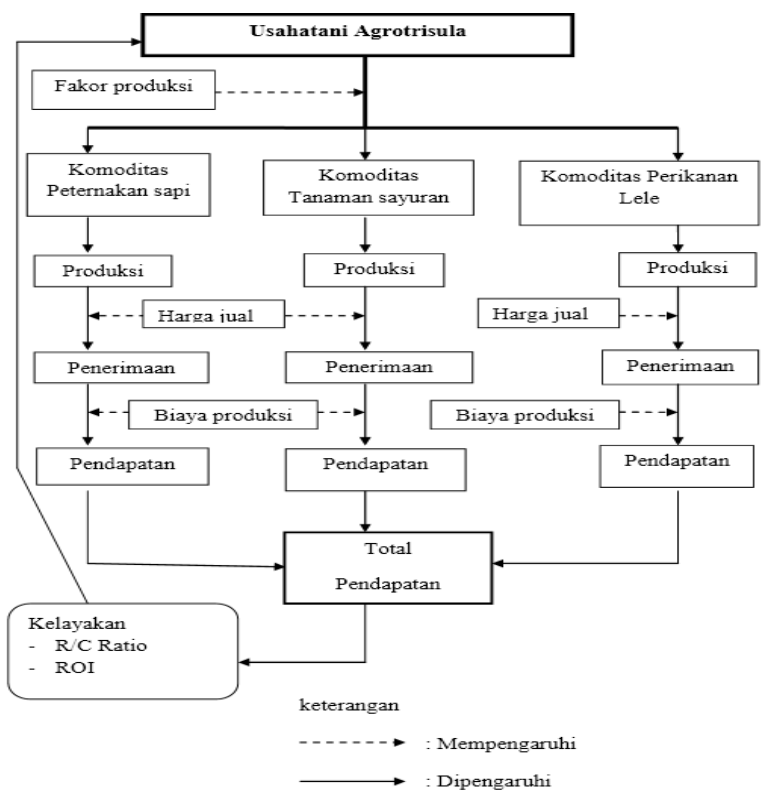

Gambar 1. Model pendekatan penelitian secara diagramatik

\section{METODOLOGI PENELITIAN}

\section{A. Tempat dan Waktu}

Penelitian ini akan dilaksanakan di Desa

Bantan kecamatan Buay Pemuka Peliung Kabupaten OKU Timur Provinsi Sumatra Selatan. Penetuan lokasi dilakukan secara sengaja dengan pertimbangan bahwa Desa tersebut merupakan salah satu Desa percontohan sistem usahatani agrotrisula di Kabupaten OKU Timur, bila dilihat secara agroklimat daerah tersebut sangat cocok untuk dikembangkan agrotrisula baik dari segi 
topografi, keadaan tanah maupun iklim. Pengumpulan data dilaksanakan sampai dengan bulan januari 2015 .

\section{B. Metode Penelitian}

Metode yang digunakan dalam penelitian ini adalah studi kasus (cese studi) terhadap kegiatan agrotrisula kelompok KBS V Desa Bantan. Studi kasus atau penelitian kasus adalah penelitian mendalam mengenai unit kerja sosial tertentu yang hasilnya merupakan gambaran yang lengkap dan teroganisir baik mengenai unit tersebut. Menurut Daniel (2002), penelitian kasus ini berusaha memberikan gambaran yang rinci dengan tekanan pada situasi keseluruhan mengenai proses atau urut-urutan suatu kajadian. Tujuan penelitian kasus secara umum untuk mendapatkan keterangan-keterangan yang rinci dan mendapatkan data yang tepat dari suatu subjek.

\section{Metode Penarikan Contoh}

Metode penerikan contoh yang digunakan dalam penelitian ini adalah sensus yang berarti seluruh populasi dijadikan sampel penelitian. Dimana kelompok KBS V merupakan satu satunya populasi yang malakukan agrotrisula di Desa Bantan. Populasi adalah wilayah generalisasi yang terdiri atas: obyek/subyek yang mempunyai kualitas dan karakteristik tertentu yang ditetapkan oleh peneliti untuk dipelajari dan kemudian ditarik kesimpulannya (Sugiyono, 2012).

\section{Metode Pengolahan Data}

Data yang diperoleh dari lapangan diolah secara tabulasi lalu dianalisa secara kualitatif dan kuantitatif. Analisis kualitatif digunakan untuk menjawab rumusan masalah yang pertama dengan penjelasan secara diskriptif berdasarkan data kualitatif yang didapat dari lapangan, sedangkan rumusan masalah kedua akan dijawap dengan analisis kuantitatif dimana data dari lapangan akan dianalisis secara matematis dan dijelaskan secara diskriptif. Analisis matematis yang digunakan dalam menghitung kelayakan usaha agrotrisula adalah sebagai berikut:

1. Untuk menghitung biaya produksi (Soekartawi, 2002), dengan rumus:

$$
\mathbf{T C}=\mathbf{F C}-\mathrm{VC}
$$

Keterangan :

$\mathrm{TC}=$ Total Cost $($ Total Biaya Produksi $(\mathrm{Rp})$

$\mathrm{FC}=$ Fixed Cost $($ Biaya Tetap $(\mathrm{Rp})$

$\mathrm{VC}=$ Varibel Cost $\{$ Biaya Variabel $(\mathrm{Rp})$
2. Untuk menghitung penerimaan digunakan rumus:

$\mathbf{R}=\mathbf{Y} \times \mathbf{P}$

Keterangan:

$\mathrm{R}=$ Revenue $/$ Penerimaan $(\mathrm{Rp})$

$\mathrm{P}=$ Price/Harga Jual $(\mathrm{Rp} / \mathrm{Kg})$

$\mathrm{Y}=$ Yield/Hasil Produksi (Kg)

3. Untuk menghitung pendapatan, digunakan rumus :

$$
\mathbf{I}=\mathbf{R}-\mathbf{T C}
$$

Keterangan:

$\mathrm{I}=$ Income $/$ Pendapatan $\mathrm{Rp}$ )

$\mathrm{R}=$ Revenue $/$ Penerimaan $(\mathrm{Rp})$

$\mathrm{TC}=$ Total Cost/total biaya (Rp)

4. Untuk menghitung $\mathrm{R} / \mathrm{C}$ Ratio digunakan rumus:

$\mathrm{R} / \mathrm{C}=\mathrm{TR} / \mathrm{TC}$

Keterangan :

$\mathrm{TR}=$ Total Revenue

$\mathrm{TC}=$ Total Cost

$\underline{\text { Kaidah }}$

- R/C>1 maka usaha layak

- $\mathrm{R} / \mathrm{C}<1$ maka usaha tidak layak

- $\mathrm{R} / \mathrm{C}=1$ maka usaha impas

5. Untuk menghitung tingkat efisiensi penggunaan modal usaha digunakan rumus sebagai berikut (Suratiah, 2010):

ROI $=I /$ investasi $x 100 \%$

Keterangan:

$\mathrm{I}=$ Income/pendapaan $(\mathrm{Rp} /$ proses $)$

Investasi $=$ Investasi $/$ modal awal usaha $(\mathrm{Rp})$

\section{HASIL DAN PEMBAHASAN}

\section{A. Kegiatan agrotrisula KBS V}

Agrotrisula merupakan suatu pola usahatani yang mengkombinasikan tiga cabang usaha bidang pertanian terdiri dari pertanaman holtikultura, peternakan dan perikanan. Kombinasi usaha yang diusahakan kelompok Komering Bangkit Sejahtera V antara lain: pertanaman holtikultura diantaranya (kacang panjang, mentimun, jagung manis, kangkung darat dan bayam cabut), budidaya ikan lele sangkuriang dan ternak sapi lokal. Cabang usaha tersebut dikelola secara terpadu dalam satu kawasan.

\section{B. Analisa Produksi Komoditi Agrotrisula \\ 1. Lahan Garapan}

Lahan garapan salah satu faktor produksi yang paling penting dan merupakan tempat tumbuh dan berlangsungya proses produksi hasilhasil pertanian . Lahan yang subur dapat memberikan peningkatan terhadap hasil pertanian. 
Lahan garapan atau luas lahan mempengaruhi kegiatan dalam proses produksi, karena semakin luas lahan garapan petani semakin besar biaya yang dibutuhkan dalam proses produksi, namun semakin besar pula penerimaan maupun pendapatan yang diterima oleh petani tersebut. Berikut tabel mengenai luas lahan garapan kegiatan model pertanian agrotrisula KBS V Desa Bantan kecamatan BP Peliung.

Tabel 1. Luas Lahan Garapan Model Usahatani Agrotrisula.

\begin{tabular}{lll}
\hline No & Jenis Komoditi & \multicolumn{1}{c}{$\begin{array}{c}\text { Luas garapan } \\
\text { (Ha) }\end{array}$} \\
\hline 1 & Kacang panjang & $1 / 16\left(625 \mathrm{~m}^{2}\right)$ \\
2 & Mentimun & $1 / 16\left(625 \mathrm{~m}^{2}\right)$ \\
3 & Jagung manis & $1 / 16\left(625 \mathrm{~m}^{2}\right)$ \\
4 & Kangkung darat & $1 / 16\left(625 \mathrm{~m}^{2}\right)$ \\
5 & Bayam cabut & $1 / 16\left(625 \mathrm{~m}^{2}\right)$ \\
6 & Ikan lele & $100 \mathrm{~m}^{2}$ \\
\hline & Total & $0,3225\left(3225 \mathrm{~m}^{2}\right)$ \\
\hline
\end{tabular}

Sumber: Olahan Data Primer Tahun, 2015.

\section{Biaya Produksi}

Untuk memperoleh suatu hasil, maka dalam suatu kegiatan produksi usahatani diperlukan korbanan-korbanan (biaya-biaya) agar produksi dapat berjalan. Dari hasil penelitian rata-rata biaya produksi yang dikeluarkan oleh pelaku usaha adalah biaya tetap (fixed cost) maupun biaya tidak tetap (variabel cost). Menurut Kartasapoetra (2003), yang dimaksut dengan biaya produksi adalah semua pengeluaran yang harus dikeluarkan produsen unuk memperoleh faktor produksi dan bahan penunjang lainya yang akan didayagunakan agar produksi yang telah direncanakan dapat terwujut dengan baik. Biaya produksi yang dikeluarkan pada kegiatan usahatani Agrotrisula KBS V Desa Bantan adalah sebagai berikut:

Tabel 2. Biaya Produksi Model Usahatani Agrotrisula.

\begin{tabular}{|c|c|c|c|c|c|}
\hline \multirow[t]{2}{*}{ No } & \multirow{2}{*}{$\begin{array}{l}\text { Keterangan } \\
\text { biaya }\end{array}$} & \multicolumn{3}{|c|}{ Jumlah Biaya ( Rp/Proses) } & \multirow{2}{*}{$\begin{array}{l}\text { Total } \\
\text { Biaya }\end{array}$} \\
\hline & & Holtikultura & Ikan Lele & Sapi & \\
\hline 1 & Investasi Awal & 1.407 .966 & 786.000 & 2.600 .000 & 4.793 .966 \\
\hline 2 & Biaya tetap & 538.667 & 204,000 & 82,500 & 586.00 \\
\hline \multirow[t]{2}{*}{3} & sarana & 1.523 .000 & 5.595 .000 & 12.000 .000 & 19.118 .000 \\
\hline & produksi & & & & \\
\hline \multirow[t]{3}{*}{4} & tanaga & 1.925 .000 & 300.000 & 450.000 & 2.675 .000 \\
\hline & kerja & & & & \\
\hline & Total & 3.986 .667 & 6.099 .000 & 12.532 .500 & 22.618 .167 \\
\hline
\end{tabular}

Sumber: Olahan Data Primer Tahun, 2015.

\section{Produksi, Harga dan Penerimaan}

Produksi merupakan hasil usaha pengolahan dari berbagai faktor baik lahan, modal, tenaga kerja dan sarana produksi lainya menjadi suatu kesatuan produk. Dalam hal ini produk yang di hasilkan model usahatani agrotrisula berupa bahan pangan bagi pemenuhan kebutuhan manusia. Yaitu berupa sayuran-sayuran dan ikan berikut adalah hasil produksi kelompok usahatani KBS $\mathrm{V}$ dengan model pertanian agrotrisula. Harga merupakan suatu nilai tukar untuk manfaat yang ditimbulkan oleh barang atau jasa yang ditukar dengan sejumlah uang berdasarkan nilai tersebut. Harga adalah masalah yang sangat penting untuk menentukan keberhasilan suatu kegiatan agribisnis.

Tabel 3. Produksi, Harga Dan Penerimaan Model Usahatani Agrotrisula.

\begin{tabular}{lllrr}
\hline No & Komoditi & Produksi/satuan & Harga (Rp) & Penerimaan (Rp) \\
\hline 1 & Kacang panjang & 1700 ikat & 2.500 & 4.250 .000 \\
2 & Mentimun & $800 \mathrm{~kg}$ & 1.500 & 1.200 .000 \\
3 & Jagung manis & $81 \mathrm{~kg}$ janten & 2.500 & 202.500 \\
& & $280 \mathrm{~kg}$ jagung & 3.500 & 980.000 \\
4 & Kangkung darat & 900 ikat & 700 & 630.000 \\
5 & Bayam cabut & 1000 ikat & 1.000 & 1.000 .000 \\
6 & Ikan lele & $583 \mathrm{~kg}$ & 16.000 & 9.328 .000 \\
7 & Sapi & 1 Jantan & 7.500 .000 & 7.500 .000 \\
& & 1 Betina & 6.000 .000 & 6.000 .000 \\
\hline & Jumlah & & & 31.090 .500
\end{tabular}

Sumber: Olahan Data Primer Tahun, 2015.

\section{Analisis Pendapatan dan Kelayakan Finansial.}

\section{Pendapatan Usahatani Agrotrisula}

Pendapatan usahatani agrotrisula bersumber dari hasil penerimaan produksi tiga cabang usahatani antara lain pertanaman, perikanan dan peternakan, dikurangi dengan total biaya produksi usahatani.

Tabel 4. Pendapatan Model Usahatani

\begin{tabular}{ccccc}
\multicolumn{3}{c}{ Agrotrisula. } & \\
\hline No & $\begin{array}{c}\text { Total Biaya } \\
(\mathrm{Rp})\end{array}$ & $\begin{array}{c}\text { Penerimaan } \\
(\mathrm{Rp})\end{array}$ & \multicolumn{2}{c}{$\begin{array}{c}\text { Pendapatan } \\
(\mathrm{Rp})\end{array}$} \\
\cline { 3 - 5 } & & & proses & bulan \\
\cline { 3 - 5 } & & & 8.472 .333 & 2.824 .111
\end{tabular}

Sumber: Olahan Data Primer Tahun, 2015.

Berdasarkan olah data primer yang dilakukan kegiatan model usahatani agrotrisula komering bangkit sejahtera di desa bantan kecamatan BP Peliung pendapatan yang diperoleh sebesar Rp. 8.472.333 dalam satu periode 
produksi dengan lama waktu tiga bulan. Jika dihitung perbulan pendapatan yang diperoleh sebesar Rp. 2.824.111/bulan.

\section{Analisis Kelayakan R/C Ratio dan ROI}

Tabel 5. Analisis R/C Ratio dan ROI Model

\begin{tabular}{cccccc}
\multicolumn{6}{c}{ Usahatani Agrotrisula. } \\
\hline No & $\begin{array}{c}\text { Total } \\
\text { Investasi } \\
(\mathrm{Rp})\end{array}$ & $\begin{array}{c}\text { Total Biaya } \\
(\mathrm{Rp})\end{array}$ & $\begin{array}{c}\text { Pendapatan } \\
\text { proses } \\
(\mathrm{Rp})\end{array}$ & $\begin{array}{c}\text { Nilai } \\
\text { R/C Ratio }\end{array}$ & $\begin{array}{c}\text { Nilai ROI } \\
(\%)\end{array}$ \\
\hline 1 & 4.793 .966 & 22.618 .167 & 8.472 .333 & 1.37 & 177
\end{tabular}

Sumber: Olahan Data Primer Tahun, 2015.

Analisis R/C Ratio yang diperoleh dari kegiatan model usahatani agrotrisula komering bangkit sejahtera V Desa Bantan dalam satu periode produksi dengan waktu tiga bulan diperoleh nilai sebesar 1,37 yang artinya setiap satu rupiah yang dikorbankan sebagai modal usaha akan mendapatkan keuntungan sebesar 1,37 rupiah. Nilai R/C $1,37>1$ dan itu artinya usahatani model agrotrisula KBS V di Desa Bantan layak untuk dikembangkan. Sedangkan pada tingkat efisiensi penggunaan modal usaha sebesar $177 \%$ dikategorikan secara finansial sangat efisien.

\section{IV.KESIMPULAN DAN SARAN}

\section{A. Kesimpulan}

Berdasarnya hasil penelitian dan analisis yang telah dilakukan, maka dapat ditarik kesimpulan sebagai berikut:

1. Kombinasi usaha yang dilakukan antara lain pertanaman holtikultura yaitu kacang panjang, mentimun, jagung manis, kangkung darat, dan bayam cabut, perikanan yaitu budidaya ikan lele sangkuriang dan perternakan yaitu budidaya sapi bali. Pengelolaan usaha dilakukan secara intensif dengan tujuan komersial, terdapat ciri khusus yang dikebangkan oleh kelompok usahatani yaitu pengaplikasian teknologi bakteri probiotik untuk memacu peningkatan hormon yang secara langsung dapat meningkatkan pertumbuhan baik tanaman, ternak maupun ikan. Konsep pertanian agrotrisula dapat menjadi sumber pendapatan harian, bulanan, dan tahunan bagi masyarakat.

2. Total luas lahan garapan yang dusahakan KBS $\mathrm{V}$ adalah 0.32 Ha.Total biaya produksi yang dikorbankan dalam satu periode produksi usahatani pola agrotrisula sebesar Rp. 22.618.167. Hasil produksi yang dihasilkan usahatani pola agrotrisula dalam satu periode produksi antara lain: 1.700 ikat kacang panajang, $800 \mathrm{~kg}$ mentimun, $81 \mathrm{~kg}$ janten, 280 $\mathrm{kg}$ jagung manis, 900 ikat kangkung darat, 1000 ikat bayam cabut, $583 \mathrm{~kg}$ ikan lele dan dua ekor sapi. Penerimaan yang diperoleh sebesar Rp. 31.091.300. Pendapatan yang diperoleh sebesar Rp. 8.712.300 dalam satu periode produksi jika dihutung perbulan maka diperoleh pendapatan sebesar $\mathrm{Rp}$. 2.904.100/bulan. Analisis R/C Ratio diperoleh nilai sebesar 1,38 yang berarti bahwa setiap satu rupiah yang dikorbankan sebagai modal usaha akan mendapatkan penerimaan sebesar 1,38 rupiah, dan berarti layak untuk dikebangakn, dan Analisis ROI (Return On Investment)diperoleh nilai sebesar $177 \%$ dan dikategorikan sangat efisien.

\section{B. Saran}

Berdasarkan penelitian dan pengamatan yang dilakukan pada usahatani pola Agrotrisula Komering Bangkit Sejahtera V Desa Bantan Kecamatan Buay Pemuka Peliung Kabupaten OKU Timur merupakan suatu penerapan konsep ekosistem alami yang memiliki hubungan timbal balik antara satu usaha komoditi pertanian dengan komoditi lainya yang saling membutuhkan. Sehingga bahan baku yang dibutuhkan tercipta dan tersedia dilingkungan tersebut, membetuk rantai makanan yang saling terkait. Jika pola usaha agrotrisula tersebut dikembangakn secara intensif memiliki prospektif yang sangat bagus selain dapat menciptakan pertanian alami, usaha dengan pola tersebut memiliki tingkat efisiensi yang tinggi terhadap penggunaan modal. Karena dapat memanfaatkan limbah-limbah yang dihasilkan oleh masing-masing komoditi usaha.

Peneliti memberikan saran kepada kelompok usahatani komering bangkit sejahtera $\mathrm{V}$ Desa Bantan untuk selalu menjaga keharmonisan kelompok, lebih giat berusaha dan mengembangkan pola agrotrisula lebih intensif tentang. Harapanya agar dapat menjadi contoh dan memberi rangsangan terhadap minat masyarakat untuk mengembangkan usahataninya dengan pola agrotrisula. Dengan demikian akan merubah pengelolaan pertanian menjadi lebih alami yang ramah lingkungan, selain dapat meningkatkan perekonomian dan kesejahteraan masayarakat.

\section{DAFTAR PUSTAKA}

Anonim. 2011. Agrobisnis. http:// ekonomi.kompasiana.com. diakses pada tanggal 27 agustus 2014. 
Anonim. 2002. Trisula. http:// id.m. Wikipedia. Org/ wiki. Diakses pada tanggal 4 januari 2015.

Anonim, 2012. Sistem Integrasi Tanaman Ternak. http://kuliah agribisnis elin. Blogspot. com. Diakses pada tanggal 4 januari 2015.

Anonim. 2013. Sistem Pertanian Terpadu.http:// blogspot. com. Diakses pada tangaal 27 agustus 2014.

Badan Litbang Pertanian. 2004. Panduan pengkajian badan penelitian dan pengembangan pertanian. Jakarta.

Daniel, M. 2002. Metode Penelitian Social Ekonomi Dilengkapi Beberapa Alat dan Analisa Penuntun Penggunaan. PT Bumi Aksana, Jakarta.

Gunawan. Surya. 2010. Kiat Sukses Budidaya Lele di Lahan Sempit. Agromedia pustaka. Jakarta.

Hernanto, F. 1995. Ilmu Usaha Tani. Penebar Swadaya. Jakarta.

Hernanto, F. 2001. Ilmu-ilmu Usaha. Penebar swadaya. Jakarta.

Harmoni, A. 2007. Studi Kelayakan Universitas Guna Darma. Jakarta.

Ibrahim, Y. 2009. Studi Kelayakan Bisnis Jilid 1. Renaka cipta. Jakarta.

Kartasapoetra. 2003. Dasar-Dasar Ilmu Usaha. LP3ES. Jakarta.

Manullang. 2000. Analisis Harga. LP3ES. Jakarta.

Narantaka, Anggit. 2012. Bisnis lele modal cekak. Javalintera. Jogjakarta.
Parnata, Ayub S. 2010. Meningkatkan hasil Pertanian dengan Pupuk Organik. PT Agromedia Pustaka. Bandung.

Ricki, dkk. 2006. Bisnis Akuntansi Manajemen. Erlangga. Jakarta.

Saragih. 2001. Suara Dari Bogor Membangun Sistem Agribisnis. Bogor. Yayasan USESE bekerjasama dengan SUCOFINDO.

Sjarkowi, F dan Sufri,M. 2004. Menejemen Agribisnis. CV. Baldad Grafiti Press. Palembang.

Sjarkowi, F. 2010. Menejemen Pembangunan Agribisnis. CV baldad Grafiti Press. Palembang.

Seokartawi. 1997. Prinsip Dasar Ekonomi Pertanian. Raja Grafindo Persada. Jakarta.

Soekartawi. 2001. Prinsip Dasar Komunikasi Pertanian. UI Press. Jakarta.

Sugiyono. 2012. Metode Penelitian Bisnis. Alfabeta. Bandung.

Suratiyah. Ken. 2006. Ilmu Usahatani. Penebar Swadaya. Jakarta.

Tim Karaya Tani Mandiri. 2010. Pedoman Bertanam Jagung.

CV Nuansa Aulia. Bandung. Tim Karaya Tani Mandiri. 2010.

Pedoman Bertanam Kacang Panjang. CV Nuansa Aulia. Bandung.

Umar, H. 1994. Studi kelayakan bisnis. PT. Raja grafindo persada. Jakarta. 